\title{
Evaluation of Field Methods for Determining Immunoglobulins in Sucking Foals
}

\author{
M. SEDLINSKÁ ${ }^{1}$, J. KREJČÍ ${ }^{2}$, M. VYSKOČIL ${ }^{3}$ \\ ${ }^{1}$ Clinic of Equine Diseases, University of Veterinary and Pharmaceutical Sciences, Brno, Czech Republic \\ ${ }^{2}$ Veterinary Research Institute, Brno, Czech Republic \\ ${ }^{3}$ Institute of Animal Breeding and Genetics, University of Veterinary and Pharmaceutical Sciences, \\ Brno, Czech Republic
}

Received July 17, 2004

Accepted November 25, 2004

\begin{abstract}
Sedlinská M., J. Krejčí, M. Vyskočil: Evaluation of Field Methods for Determining Immunoglobulin in Sucking Foals. Acta Vet. Brno 2005, 74: 51-58.

The aim of the study was to evaluate quick and easy semiquantitative tests for the detection of serum immunoglobulins that are commonly used for to trace the foals with the failure of passive immunity transfer. We compared the four most employed methods - zinc sulphate turbidity tests using photometric or visual reading, glutaraldehyde test and refractometric determination of total protein concentration in serum. Radial immunodiffusion test was used as a reference method. Thirty-eight blood serum samples from foals were used for quantitative estimation of immunoglobulins. The tested methods were correlated with reference method and their availability for tracing of cases of unsuccessful passive transfer immunogobulins was evaluated.

The results obtained so far have not allowed us to recommend without reservation any of the compared methods as a reliable test for the determination of blood serum Ig concentrations in newborn foals. On the other hand, the practical usefulness of two of the tested methods (visual reading of turbidity, refractometry) for rapid field identification of hypogammaglobulinaemic foals was confirmed. Of the two, we prefer the refractometric method (sensitivity: 94.11 ; specificity: 83.30 and predictive value: 88 ) for common use because it is quicker and easier than other methods. This study pointed out the critical points of the mentioned problem, which have to be studied further.
\end{abstract}

Foal, IgG, immunoglobulins, glutaraldehyde, zinc sulphate turbidity test, refractometry, FPT

The immune system of newborn foals is not sufficiently developed despite the fact that equine foetuses are capable of immune reactions to antigenic stimuli (Naylor 1979). Compared with the adult horses, immune reactions of foals are slower and weaker in terms of antibody production (Tizard 2000). Therefore, newborn foals can quickly succumb to infections, which pose only minor problems in adult animals. Their ability to resist to the common infections depends on passive intake of maternal antibodies. The epitheliochorial placenta of equids, in which the foetal and the maternal circulations are markedly separated from each other, makes transplacental transfer of immunoglobulins impossible. Only the absorbed colostral antibodies provide the antibody protection in newborn foals that are therefore a significant factor influencing their morbidity and mortality (McGuire et al. 1977).

Blood serum IgG concentrations exceed $8 \mathrm{~g} \cdot \mathrm{l}^{-1}$ in most foals aged 24 to $48 \mathrm{~h}$. Finding of IgG concentrations from 4 to $8 \mathrm{~g} \cdot \mathrm{l}^{-1}$ is interpreted as a partial, and that below $4 \mathrm{~g} \cdot \mathrm{l}^{-1}$ as a total failure of passive antibody transfer (FPT). All these values were determined by the radial immunodiffusion metod. FPT affects 2.9 to $25 \%$ of newborn foals and has thus become the most frequently occurring cause of neonatal septic infections (Hines 1997). As the resistance of hypogammaglobulinaemic foals is compromised, up to $50 \%$ of that foals are affected by an infection in the first week after birth (Naylor 1979). Such infections can be

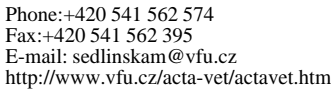


prevented by administration of different homologous immunoglobulin preparations to hypogamaglobulinaemic foals provided that immunoglobulin concentrations in 24 to 48 hour-old foals are known. Thus, simple solution of the FPT problem consists in gammaglobulin assessment in all newborn foals and preventative application of equine serum preparations containing equine immunoglobulins to FPT-affected ones. Advantages and effectiveness of such a procedure have been previously demonstrated (TylerMcGowan et al. 1997).

Equine practitioners need rather a test for the identification of FPT-affected foals than an accurate method yielding quantitative results within the whole range of immunoglobulin concentrations. Such field test should be simple, quick, cheap and appropriately reliable. Instrumental laboratory methods of the immunoglobulin determination are rather laborious and time consuming. The commercial tests of the former type are not yet common. In case they exist (Pusterla et al. 2002), they are inadequately expensive and thus unsuitable for preventive examinations of all foals born in large rearing facilities. The objective of this study was to test and compare the available field methods, most frequently employed for FPT determination. They will be compared with a reference quantitative method (radial immunodiffusion). The abilities of those methods to identify FPT-affected foals will be evaluated.

\section{Materials and Methods}

Origin and processing of blood serum samples

The experiment was carried out using 38 blood serum samples collected from thoroughbred (26) or warmblooded (12) foals of various ages (1-98 days) and both sexes (22 fillies and 16 colts), reared on the University farm or hospitalised for various reasons at the Clinic of Equine Diseases of the University of Veterinary and Pharmaceutical Sciences, Brno.

The samples were collected from $v$. jugularis into anticoagulant-free transport tubes. Blood sera were separated by centrifugation and kept at $-20{ }^{\circ} \mathrm{C}$ until examined by all the tested and reference procedures.

Determination of immunoglobulin concentration

Radial immunodiffusion (RID) test: standard procedure as described by Mancini et al. (1965) using glass plates and rabbit anti-horse IgG prepared in our laboratory (Veterinary Research Institute, VRI Brno). The results (diameters of precipitating rings) were read after $24 \mathrm{~h}$ of diffusion at room temperature in humidified atmosphere and the actual values were derived from calibration curves plotted for each plate separately. The values of four dilutions of the standard horse IgG, diluted with $5 \%$ bovine serum albumin were plotted on the calibration curve. Purified horse IgG was also prepared in the laboratory of VRI Brno.

Zinc sulphate turbidity reaction (ZST): turbidity induced by addition of zinc sulphate was measured using the following modification of the McEvan's method (McEvan et al. 1970): $25 \mu \mathrm{L}$ of the tested serum was mixed with $1.7 \mathrm{~mL}$ of $0.7 \mathrm{mM}$ zinc sulphate $\left(208 \mathrm{mg} \cdot 1^{-1}\right), \mathrm{pH}$ 5.8. The mixture was shaken and left to stand at room temperature for $2 \mathrm{~h}$. Light absorption due to turbidity was measured photometrically at $590 \mathrm{~nm}$ (Spekol 11, Carl Zeiss, Jena Germany). Blood serum mixed with PBS at the same ratio was used as the blank. The immunoglobulins contents of the tested sera were derived from a calibration curve plotted on a basis of turbidity values corresponding to four dilutions of the standard serum samples (Precinorm Protein, Roche).

Zinc sulphate turbidity reaction - the visual readings (ZSTV) of the density of turbidity were performed by a comparative method. The turbidities of the tested samples, obtained by the zinc sulphate reactions, were compared to the turbidities of five dilutions of the standard serum $\left(4,8,10,15,20 \mathrm{~g} \cdot \mathrm{l}^{-1}\right)$.

Glutaraldehyde coagulation test: the principle of the method consists in differential coagulation of different protein fractions of blood serum in diluted aldehyde solutions. The Beetson's modification (Beetson et al. 1985) of the test was used as follows: blood serum samples were mixed at 10:1 with $10 \%$ glutaraldehyde solution and coagulation of the mixture was checked at $5,10,15,20,30,45$, and $60 \mathrm{~min}$. In the original version, coagulation within 10, 60 and more than 60 min indicated Ig concentrations: $8 \mathrm{~g} \cdot \mathrm{l}^{-1}, 4$ to $8 \mathrm{~g} \cdot \mathrm{l}^{-1}$, and less than $4 \mathrm{~g} \cdot \mathrm{l}^{-1}$, respectively. As a standard were used tree dilutions of horse serum diluted with bovine albumin $\left(8 \mathrm{~g} \cdot \mathrm{l}^{-1}, 4 \mathrm{~g} \cdot \mathrm{l}^{-1} \mathrm{and} 2 \mathrm{~g} \cdot \mathrm{l}^{-1}\right)$

Refractometry: total blood serum protein concentration was determined by change in light refraction index, which was measured using a pocket refractometer (American optical corp.). A specialised relevant table was used to convert the readings into protein concentrations. This method determines the total content of serum proteins. From the obtained values immunoglobulin content is calculated by the procedure described below.

Data analysis

Statistical processing

The evaluated orientation methods were compared to the reference - RID method. The coefficient of determination (R2) was calculated for each group as a rate of linear regression. Furthermore, a linear 
regression function was calculated; their pertinences were characterized by residual sums of squares of the determined.

Calculations were performed with the assistance of a statistical software package Microsoft Excel and Stat Plus (Matoušková et al. 1992)

Table 1. Correlation between the evaluated and reference methods and evaluation of their reliability.

\begin{tabular}{|l|c|c|c|}
\hline Method & $\mathrm{ZnSO}_{4}$ - photometrical $\mathrm{m}$. & $\mathrm{ZnSO}_{4}$ - visual m. & Refractometry \\
\hline Number of values & 38 & 35 & 35 \\
\hline $\begin{array}{l}\text { Coefficient of } \\
\text { determination } \mathrm{R}^{2}\end{array}$ & 0.873 & 0.775 & 0.475 \\
\hline $\begin{array}{l}\text { Residual sum of } \\
\text { squares } \Sigma \Delta^{2} \mathrm{Y}\end{array}$ & 285.7 & 479.9 & 1118.6 \\
\hline Sensitivity (\%) & not calculated & 94.11 & 94.11 \\
\hline Specificity (\%) & not calculated & 72.22 & 83.33 \\
\hline Predictive value (\%) & not calculated & 83 & 88 \\
\hline
\end{tabular}

Analysis of reliability of methods for FPT detection

Except for a correlation between the evaluated and reference methods, expressed as a coefficient of determination and residual sums of squares (Table 1), the tested methods were also compared according to their ability to detect foals affected by the FPT (Fig. 4 and 5). Specificity, sensitivity and predictive values for compared method were calculated (Motulský 1995).

For comparison of the examined methods only values of 35 serum samples with IgG lower than $30 \mathrm{~g} \cdot \mathrm{l}^{-1}$ (determined by an RID method) were used. The real quantity of IgG could not be measured by those methods in the sera with contents of IgG higher than that level.

\section{Results}

Photometric reading of zinc sulphate turbidity reaction

Corresponding samples examined by zinc sulphate turbidity reaction showed almost double values than the same samples examined by RID method (Fig. 1). This fact could by explained by the use of different standard sera. Neglecting this fact, we can say that both testing methods showed a high degree of correlation evaluated by coefficient of determination (R2) (Table 1). Lower degree of coincidence was found in the set of values from $0 \mathrm{~g} \cdot \mathrm{l}^{-1}$ to $20 \mathrm{~g} \cdot \mathrm{l}^{-1}$ (RID) in the range of values of our interest. Moreover, in this interval the most pronounced deviations of theoretical values calculated from a regress equation and the values determined by the reference method (RID) were found.



Fig. 1. Comparison of the turbidimetric method - photometric reading, with RID as a reference method for the determination of the immunoglobulins in the horse serum. 
Visual reading of zinc sulphate turbidity reaction

Zinc sulphate treated samples were matched against a series of turbidimetric standards placed in a comparator. A statistic comparison of values determined by this method and values determined by the RID method is summarized in Tab. 1 and Fig. 2. A low degree of correlation of both the methods is obvious. Despite this fact, this method for tracing the foals affected by the FPT could be used. We tested applicability of this method for that purpose of the FPT tracing by comparison of the results obtained by that method with results obtained by the RID method. In case we used the turbidity (visual reading) corresponding to $15 \mathrm{~g} \cdot \mathrm{l}^{-1}$ of immunoglobulins as a selection limit for FPT detection, we found all but one FPTaffected foal (false negative). On the other hand, in that case, 5 foals were mistakenly considered as affected by FPT (false positive) (Fig. 4). If the selection limit was reduced to a value of the turbidity corresponding to $10 \mathrm{~g} \cdot 1^{-1}$ of immunoglobulins, the ratio of false results changed to $3 / 0$ (negative/positive).



Fig. 2. Comparison of the turbidimetric method visual reading, with RID as a reference method for the determination of the immunoglobulins in the horse serum.

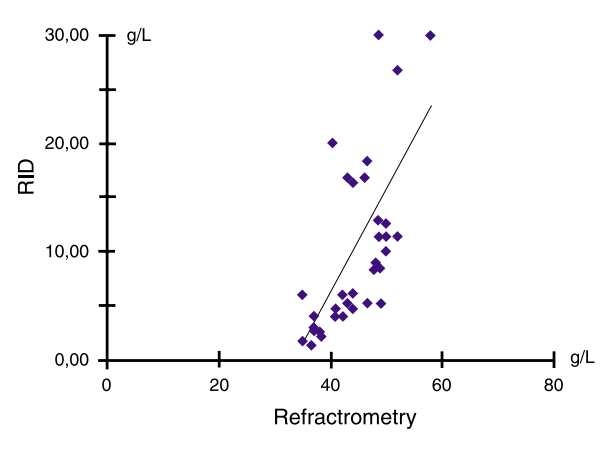

Fig. 3. Comparison of the refractometric method with RID as a reference method for the determination of the immunoglobulins in the horse serum.

\section{Glutaraldehyde test}

This easy and rapid test showed to be less reliable than other similar methods. Reliable results were obtained only in foals with immunoglobulin levels higher than $18 \mathrm{~g} \cdot \mathrm{l}^{-1}$ or lower than $4 \mathrm{~g} \cdot \mathrm{l}^{-1}$. The infallibility of the test in detection of FPT-affected foals was only $50 \%$ in animals with immunoglobulin levels within these ranges $\left(4 \mathrm{~g} \cdot \mathrm{l}^{-1}-18 \mathrm{~g} \cdot \mathrm{l}^{-1}\right)$. Besides, reproducibility of the method in repeated examinations was low.

Refractometric determination of protein concentration

Correlations expressed as a regression line showing a relationship between reference and refractometry method is plotted on Fig. 3. After extension of the straight line in direction of axis $\mathrm{x}$ the regression line cross the axis $\mathrm{x}$ in a point equal to the concentration of proteins $34 \mathrm{~g} \cdot \mathrm{l}^{-1}$. We can consider this value as a sum of serum proteins except for immunoglobulins. The values measured above that limit correspond to the concentration of immunoglobulins. Total serum protein concentration of $44 \mathrm{~g} / \mathrm{L}$ corresponding to an immunoglobulin concentration of approximately $10 \mathrm{~g} \cdot \mathrm{l}^{-1}$, can be accepted as the critical limit for FPT determination. The statistic results expressing a degree of correlation of this method and the reference one (Table 1) show only a loose relationship with a great variability in the range values higher than $15 \mathrm{~g} \cdot \mathrm{l}^{-1}$ of immunoglobulins. In spite of this, reliability of this method, in respect to identification of FTP- affected foals can be evaluated as useful. In Fig 5, the results 
of refractometric identification of FPT- affected foals are summarised, in case that the selection limit $44 \mathrm{~g} \cdot \mathrm{l}^{-1}$ of serum proteins (corresponding approximately to $10 \mathrm{~g} \cdot \mathrm{l}^{-1}$ immunoglobulins) was used. In this event, only one of tested foals was false FPT-negative and three of tested foals were false positive.

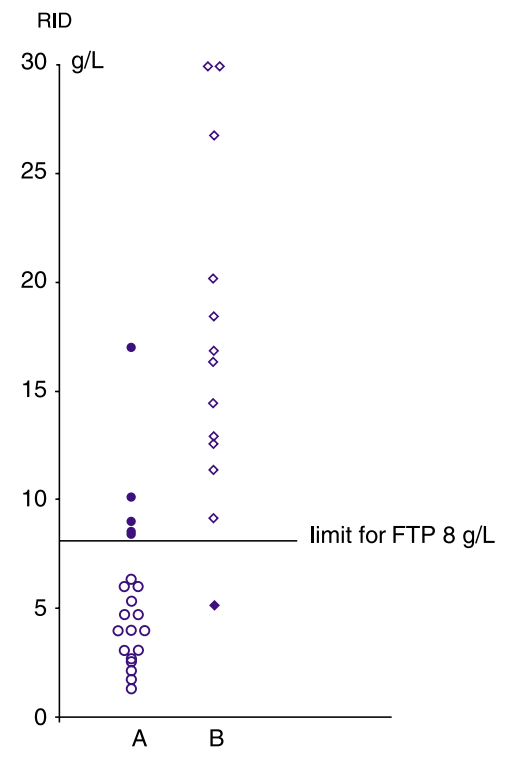

Fig. 4. Reliability of the method using visual reading of the zinc sulphate turbidity in respect to identification of FPT affected foals.

The results obtained by the RID method in foals classified by ZSTV as:

A) hypogammaglobulinaemic $\left(\leq 8 \mathrm{~g} \cdot \mathrm{l}^{-1}\right)$ (circles; full circles - false FPT positive); B) normoglobulinaemic $\left(>8 \mathrm{~g} \cdot \mathrm{l}^{-1}\right.$ ) (squares; full squares false FPT- negative).



Fig. 5 Reliability of the refractometric method in respect to identification of FPT affected foals.

The results obtained by the RID method in foals classified by refractometry as:

A) hypogammaglobulinaemic $\left(\leq 10 \mathrm{~g} \cdot \mathrm{l}^{-1}\right)$ (circles; full circles - false FPT positive);

B) normoglobulinaemic $\left(>10 \mathrm{~g} \cdot \mathrm{l}^{-1}\right)$ (squares; full squares - false FPT- negative).

\section{Discussion}

The results presented in this study allow us to conclude that the zinc sulphate test combined with turbidimetry can be used for the laboratory determination of gammaglobulin concentration in foal blood sera. Compared with radial immunodiffusion as the generally accepted reference method, turbidimetry is much simpler, less expensive and more rapid. Its drawbacks include the dependence on laboratory background with special equipment, as well as the dependence of results on a number of factors, such as time, temperature, and particularly $\mathrm{pH}$ of the reaction mixture (absorption of carbon dioxide results in significant shifts of $\mathrm{pH}$ ). The effects of such factors can be corrected by the use of standard sera. Radial immunodiffusion is less dependent on such factors, can be done in field conditions, but the procedure is rather time-consuming. This is the reason to use it mostly for quantitative determination of immunoglobulin classes.

Visual reading of results of the zinc sulphate turbidity test can also be used as a method for the identification of FPT-affected foals, in spite of low correlation with the reference 
method. The critical value for FPT determination must be, in case of this method, increased to $15 \mathrm{~g} \cdot \mathrm{l}^{-1}$. In that case the method allows reliable differentiation of foals at risk. A serious drawback is the dependence of the final turbidity on $\mathrm{pH}$ of the zinc sulphate solution. Prolonged storage or even a short exposure to atmospheric carbon dioxide considerably changes $\mathrm{pH}$ and affects the result of the reaction. The possible ways of overcoming this problem are buffering or the use of $\mathrm{pH}$ indicators.

Another way to overcome the above mentioned disadvantage is replacing the turbidity standards used in comparators by the standard blood sera diluted so as to contain $4,8,10$, and $12 \mathrm{~g}$ of immunoglobulins per litre. Such sera would be processed along with the tested samples and used for indication of critical immunoglobulin concentrations.

The simple glutaraldehyde test has been used and recommended for a rapid differentiation between FPT-affected and normoglobulinaemic foals by several authors (Sandholm 1974, 1976; Tennat et al. 1979; Beetson et al. 1985; Clabough et al. 1989). The principle of the method consists in polymerisation by glutaraldehyde of gammaglobulins, which precedes that of other blood serum proteins. Addition of $10 \%$ of glutaraldehyde to a normogammaglobulinaemic serum, results in gelification within several minutes, while in hypogammaglobulinaemic sera, the process is either delayed by dozens of minutes or does not take place at all. Our attempts to reproduce these results failed. Batches of the glutaraldehyde, supplied by different manufactures, even the freshest ones, yielded inconsistent results. Although this chemical is known for its instability and must be supplied in flasks with absorption balls and paraffin sealed caps, none of the authors mentioned above pointed out the importance of using fresh solutions and specified the manufacturer of glutaraldehyde used in his experiments. Noteworthy in our experiments was the finding that the results depended rather on the characteristics of serum samples than on the batch of glutaraldehyde. In other words, irrespective of the batch used, some sera yielded results, which strikingly contradicted the actual content of immunoglobulins. It may be due to the action of some factors characteristic for the tested sera, which also affected the results of the glutaraldehyde test. Our set of the tested sera was too small for the identification of such factors. In any case, the results obtained so far do not allow us to recommend the glutaraldehyde test for field use.

Although light refraction index of blood serum indicates total protein concentration, refractometry can be used for testing of newborn foal blood sera for gammaglobulin concentration, because the concentrations of other protein fractions are constant. It can therefore be assumed that any change in light refraction index reflects a change in the intake and/or absorption of colostral immunoglobulins. Blood serum refractometry was successfully used in bovine practice for the assessment of postpartum care and of the rate of colostrum intake by newborn calves. The major benefits of the refractometric method are that the only necessary instrument is a simple refractometer, such as the pocket type used in sugar manufacture, and that the result can be obtained immediately after blood serum separation. However, the results, mentioned above, demonstrate only loose relationship between results obtained by refractometry and reference method. When all measured values were compared, relatively low correlation was observed. If the values within the critical range of 0 to $15 \mathrm{~g} \cdot \mathrm{l}^{-1}$ (measured by RID method) are compared, congruency of both the methods is markedly higher $\left(\mathrm{R}^{2}=0.725\right)$. For that reason, the method may be recommended to trace the foals affected by FTP. Applicability of this method to trace the hypogammaglobulinemic foals is demonstrated in Fig. 5 and Table 1. The results are comparable with those obtained by other semi-quantitative methods, including the newly introduced semi-quantitative immunoenzymatic test (SNAP test) (Pusterla et al. 2002). Together with other advantages, this is the reason why we can recommend this method for common use in veterinary practice, mainly in large breeding farms. 
However, refractometry can only be used for FPT detection in newborn foals because the total contents of blood serum proteins gradually change with ageing, as documented long since by Rumbough et al (1978). Should the tested methods be used under the field conditions, it would be necessary to consider that the limits of FPT evaluation specified by McGuire at al (1977) are only valid for the RID method used in their study. If is necessary to set specific limits for the other methods using quantitative evaluation, as it was performed in our study. The same approach was used by Tyler et al. (1996) and Hud gen s at al. (1996) who recommended refractometric method or visual reading of zinc sulphate turbidity test respectively for rapid FPT assessment in calves.

In conclusion, the results obtained so far have not allowed us to recommend without reservation any of the compared methods as a test for the determination of blood serum Ig concentration in newborn foals. On the other hand, partial usefulness of two of the tested methods (visual reading of turbidity, refractometry) for rapid field identification of FPT affected foals was confirmed. Of the two, we prefer the refractometric method for common use because it is quicker and easier to use than other methods. This pilot study only revealed critical points as an objective for further research that will be aimed at the development of a set or a standard procedure for a rapid and sensibly reliable detection of FPT affected foals.

\section{Hodnocení rychlých diagnostických metod pro detekci hypogamaglobulinemie u hř́bat}

Cílem studie bylo zhodnotit použitelnost a spolehlivost rychlých diagnostických metod používaných pro detekci imunoglobulinů v séru hříbat. Vybrány byly čtyři metody běžně používané pro vyhledávání hříbat, u kterých došlo k selhání pasivního přenosu protilátek (FPT) - fotometrické a vizuální odečítání zinksulfátové reakce, glutaraldehydový test a refraktometrické stanovení koncentrace bílkovin v séru. Jako referenční metoda byla použita metoda radiální imunodifúze. Pro vyšetření jsme použili 38 vzorků krevní sér hříbat různého věku. Získané výsledky byly statisticky vyhodnoceny z hlediska vzájemné korelace s referenční metodou. Kromě toho byly metody posouzeny $\mathrm{z}$ hlediska spolehlivosti př́i diagnostice FPT hříbat (senzitivita, specifita a prediktivní hodnota).

Dosažené výsledky neumožňují zcela jednoznačně doporučit některou $\mathrm{z}$ námi porovnávaných metod pro spolehlivé stanovení obsahu imunoglobulinů v séru hř́ibat. Na druhé straně byla prokázána použitelnost dvou z testovaných metod (vizuální odečítání zinksulfátové reakce a refraktometrie) pro orientační vyhledání FPT hříbat v terénních podmínkách. Z nich, pro praktické použití doporučujeme refraktometrii (senzitivita: 94,11; specifita: 83,30 a prediktivní hodnota: 88) pro její snadnost a rychlost provedení. Tato práce odhalila kritická místa studované problematiky, která nejsou v doprovodných literárních zdrojích běžně uváděna.

\section{Acknowledgements}

The study was supported by the Ministry of Agriculture of the Czech Republic (MZE-0002716201) and Ministry of Education, Youth and Sports of the Czech Republic (CEZ-J 16/98: 161700002)

\section{References}

BEETSON, SA, HILBERT, BJ, MILLS, JA 1985: The use of the glutaraldehyd coagulation test for detection of hypogammaglobulinaemia in neonatal foals. Aust vet J 62: 279-281

CLABOUGH, DL, CONBOY, SH, ROBERTS, MC 1989: Comparison of four screening techniques for the diagnosis of equine neonatal hypogammaglobulinemia. J Am Vet Med Assoc 194: 1717-1720

HINES, MT 1997: Immunodeficiencies of Foals. In: Robinson NE. Current Therapy in Equine Medicine. Philadelphia, WB Saunders, pp. 581-586 
HUDGENS KAR, TYLER JW, BESSER TE, KRYTENBERG DS (1996): Optimizing performance of qualitative zinc sulfate turbidity test for passive transfer of immunoglobin $G$ in calves. Am J Vet Res 57: 1711-1713

MANCINI, G, CARBONARA, AO, HEREMANS, JF 1965: Immunochemical quantitation of antigens by simple radial immunodiffusion. Immunchemistry 2: 235-254

MATOUŠKOVÁ, O, CHALUPA J, CÍGLER M, HRUŠKA K 1992: STAT Plus - application manual, Brno. Veterinary Research Institute: p. 168-174.

McEVAN, AD, FISHER, EW, SELMAN, IE, PENHALE, WJ 1970: A turbidity test for the estimation of immune globulin levels in neonatal calf serum. Clin Chim Acta 27: 155-163

McGUIRE, TC, CRAWFORD, TB, HALLOWELL, AL, MACOMBER, LE 1977: Failure of colostral immunoglobulin transfer as an explanation for most infection and deaths of neonatal foals. J am Vet Med Assoc 170: $1302-1304$

MOTULSKY H 1995: Intuitive Biostatistics. Oxford University Press, Inc. pp. 129-132

NAYLOR, JM 1979: Colostral Immunity in the Calf and the Foal. In: The Veterinary Clinics of North America, Gastroenterology, pp. 331-358

PUSTERLA, N, BERGER, J, SPIER, JS, PUGET, B, WATSON, JL 2002: Evaluation of the SNAP foal IgG test for the semi quantitative measurement of immunoglobulin $G$ in foals. Vet Rec 151: 258-260

RUMBAUGH GE, ARDANS AA, GINNO D, TROMMERHAUSSEN-SMITH A (1978): Measurement of neonatal equine immunoglobulins for assessment of colostral immunoglobulin transfer: comparison of single radial immunodiffusion with the zinc sulphate turbidity test, serum electrophoresis, refractometry for total serum protein, and the sodium sulfite precipitation test. J Am Vet Med Assoc 172: 321-325

SANDHOLM, M 1974: A Preliminary report of rapid method for the demonstration of abnormal gammaglobulin levels in bovine whole blood. Res Vet Sci 17: 32-35

SANDHOLM, M 1976: Coagulation of Serum by Glutaraldehyde. Clin Biochem 9: 39-41

TENNANT, B, BALDVIN, BH, BRAUN, RK, NORCROSS, M, SANDHOLM, M 1979: Use of the glutaraldehyde coagulation test for detection of hypogammaglobulinemia in neonatal calves. J Am Vet Med Assoc 174: 848-852

TIZARD, I 2000: Immunity in the Fetus and Newborn Animal. In: Veterinary Immunology: An Introduction 6th ed. WB Saunders, pp. 210-221

TYLER JW, HANCOCK DD, PARISH SM, REA DE, BESSER TE, SANDERS SG, WILSON LK 1996: Evaluation of 3 assays for failure of passive transfer in calves. J Vet Intern Med 10: 304-307

TYLER-McGOWAN, CM, HODGSON, JL, HODGSON, DR 1997: Failure of passive transfer in foals: incidence and outcome on four studies in New South Wales. Aust Vet J 75: 56-59 